Columbia Law School

Scholarship Archive

2013

\title{
Comments on ALRC Discussion Paper 79, Copyright and the Digital Economy
}

June M. Besek

jbesek@law.columbia.edu

Jane C. Ginsburg

Columbia Law School, jane.ginsburg@law.columbia.edu

Philippa Loengard

ploengard@law.columbia.edu

Follow this and additional works at: https://scholarship.law.columbia.edu/faculty_scholarship

Part of the Intellectual Property Law Commons

\section{Recommended Citation}

June M. Besek, Jane C. Ginsburg \& Philippa Loengard, Comments on ALRC Discussion Paper 79, Copyright and the Digital Economy, COLUMBIA UNIVERSITY SCHOOL OF LAW, THE KERNOCHAN CENTER FOR LAW, MEDIA \& THE ARTS (2013).

Available at: https://scholarship.law.columbia.edu/faculty_scholarship/1830

This Working Paper is brought to you for free and open access by the Faculty Publications at Scholarship Archive. It has been accepted for inclusion in Faculty Scholarship by an authorized administrator of Scholarship Archive. For more information, please contact scholarshiparchive@law.columbia.edu. 


\title{
The Kernochan Center for Law, Media and the Arts Columbia University School of Law
}

\section{Comments on ALRC Discussion Paper 79, Copyright and the Digital Economy}

\author{
By June M. Besek, Jane C. Ginsburg and
}

Philippa S. Loengard ${ }^{1}$

\footnotetext{
${ }^{1}$ June M. Besek is the Executive Director of the Kernochan Center for Law, Media and the Arts and a Lecturer in Law at Columbia University School of Law. Jane C. Ginsburg is the Morton L. Janklow Professor of Literary and Artistic Property Law at Columbia and the Faculty Director of the Kernochan Center. Philippa Loengard is the Assistant Director of the Kernochan Center and a Lecturer in Law at Columbia. More detailed biographies are included at the end of these comments. We also gratefully acknowledge excellent research assistance from Karen Kim, Columbia Law School Class of 2015.
} 
Executive Summary.....................................................................................................................

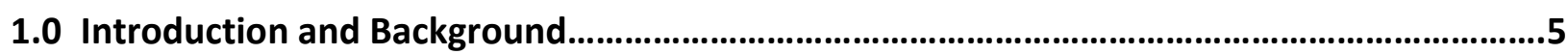

2.0 The Uncertainty Inherent in Fair Use...................................................................................6

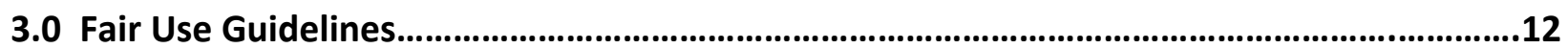

4.0 If the ALRC's Recommendations Were Enacted, the Fair Use Exception in Australia Could Be Broader Than in the US............................................................................................14

4.1 "Standing in the Shoes" .............................................................................................14

4.2 Invalidating Contracts...................................................................................................17

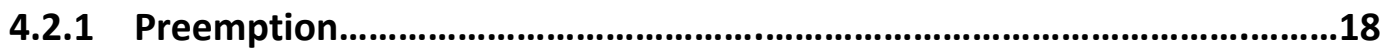

4.2.2 Copyright Misuse..................................................................................19

5.0 Technological Protection ..........................................................................................................20

6.0 Conclusion 


\section{The Kernochan Center for Law, Media and the Arts Columbia University School of Law}

\section{Comments on ALRC Discussion Paper 79, Copyright and the Digital Economy}

\section{Executive Summary}

We provide these comments in connection with the Australian Law Reform Commission's ongoing study of copyright and the digital economy, and in particular its request for comments on the recommendations put forth in its Discussion Paper 79 (June 2013). We focus on US law, and how the US experience bears on the possibility of an open-ended uncompensated "fair use" type exception in Australia, and other related issues.

The fair use doctrine in the US provides great flexibility, but that flexibility in many instances comes at the cost of certainty and predictability. We are not suggesting that reasonable judgments cannot be made about whether a particular use is fair; certainly experienced practitioners make such judgments daily. But fair use decisions are often complicated, and advice frequently depends as much on the amount of risk the user is willing to undertake as it does on the evaluation of the substantive law. Our point is not that fair use caselaw absolutely resists synthesis, but rather that the synthesis most successfully occurs at a high level of abstraction; individual actors, by contrast, need to know whether their particular plans will run afoul of the law.

Legal literature has seen many attempts over the years to simplify or clarify fair use, both descriptive and prescriptive. But it would be premature to conclude that the law of fair use is or soon will be coherent and predictable. Guidelines could theoretically help in interpreting fair use, but the weight and value of guidelines depends on how they were developed.

The ALRC Discussion Paper's proposals could result in a broader fair use doctrine in Australia than in the US. Notably, fair use in Australia, as in the US, would exempt certain uses without countervailing compensation. But the proposed Australian version may embrace a greater range of commercial actors, thus altering the balance. The proposals include additional illustrative purposes; they would also permit commercial users to stand in the shoes of clients entitled to exceptions. The ALRC also proposes that contracts or contract provisions that attempt to bargain around library exceptions and certain fair use exceptions would be unenforceable. In the US, contracts concerning copyrighted materials are usually upheld. As a general rule, contract preemption does not serve to invalidate contract provisions that limit the exercise of copyright exceptions, and the doctrine of copyright misuse does so only in the most egregious of cases. 
Finally, in the US there is no exemption from anti-circumvention of technological access controls for such broad purposes as "exercising fair use" or "making noninfringing use." Certain narrow fair uses have been deemed exceptions pursuant to a triennial rulemaking conducted by the Copyright Office, but those exceptions must be revisited every three years. 


\title{
The Kernochan Center for Law, Media and the Arts Columbia University School of Law
}

\section{Comments on ALRC Discussion Paper 79, Copyright and the Digital Economy}

\author{
By June M. Besek, Jane C. Ginsburg \\ and Philippa S. Loengard
}

\subsection{Introduction and Background}

The Kernochan Center for Law, Media and the Arts is part of Columbia Law School in New York. The Kernochan Center's program for Intellectual Property Studies and Law Reform seeks through research, study and publication to help resolve problems that new technologies pose for authors and users.

These comments respond to Copyright and the Digital Economy, Discussion Paper 79 (June 2013), of the Australian Law Reform Commission (ALRC). That discussion paper is part of the ALRC's ongoing effort to determine whether the existing exceptions in Australian copyright law are sufficient to promote creativity and innovation in the digital economy, and whether they should be changed.

We appreciate this opportunity to comment on the ALRC's very thoughtful Discussion Paper, which covers a wide range of issues and clearly represents an enormous undertaking. Our earlier report, Copyright Exceptions in the United States for Educational Uses of Copyrighted Works, ${ }^{2}$ submitted in response to the ALRC's Copyright and the Digital Economy Issues Paper, addressed US copyright exceptions applicable to educational uses of copyrighted works, including fair use. These comments further expand, and in some cases refine, our earlier report. To avoid unnecessary duplication, we assume familiarity with that report. These comments focus primarily on the fair use exception in US copyright law, and related issues.

In broad brush, ALRC Discussion Paper 79 recommends

- Adopting a new fair use exception, with statutory factors similar to those of the US but with additional illustrative purposes, including education; non-consumptive use; private and domestic use; and public administration.

- Repealing existing fair dealing and other specific exceptions.

\footnotetext{
${ }^{2}$ Available at http://www.alrc.gov.au/inquiries/copyright-and-digital-economy/submissions-receivedalrc, Comment 291 [hereinafter, Kernochan Center Report.]
} 
- Alternatively, if a broad fair use exception is not enacted, the ALRC recommends incorporating the fairness factors into the fair dealing exceptions, and adding more fair dealing exceptions (for the purposes listed above).

- Repealing the statutory licenses for educational and other institutions in VA and VB.

- Providing that license agreements should be deemed invalid to the extent that their terms exclude or limit the operation of certain fair use or fair dealing exceptions and library exceptions.

The ALRC Discussion Paper also suggests that an exemption from anti-circumvention provisions for certain types of fair use and library use "may be justified, ${ }^{3}$ though it acknowledges that anti-circumvention is outside of its purview.

We begin in section 2.0 by discussing the uncertainty inherent in fair use as it has been applied in the United States. In section 3.0 we expand our discussion of fair use guidelines. Section 4.0 explains some ways in which the fair use regime proposed for Australia could be broader than that of the United States, including the possibility that commercial entities would be permitted to "stand in the shoes" of users they service, and the interplay between contracts and the fair use exception. In section 5.0 we discuss fair use and the protection for technological means of protecting copyrighted works as provided in section 1201 of Title 17. Finally, we conclude in section 6.0 .

\subsection{The Uncertainty Inherent in Fair Use}

The ALRC Discussion Paper suggests that the law concerning fair use is consistent and predictable. ${ }^{4}$ As far as US law is concerned, this is a rather optimistic assessment. Many in the United States - including users, legal practitioners and courts - do not regard the law of fair use as consistent and predictable, although they wish it were. The US benefits from the flexibility of the fair use exception, but that flexibility comes at a cost. Courts have described the issue of fair use as "the most troublesome in the whole law of copyright," ${ }^{5}$ a sentiment shared by

${ }^{3}$ ALRC Discussion Paper at 377.

${ }^{4}$ Id. at 79.

${ }^{5}$ Dellar v. Samuel Goldwyn, Inc., 104 F.2d 661, 662 (2d Cir. 1939) (per curiam). Accord, Monge v. Maya Magazines, Inc., 688 F.3d 1164, 1170 ( $9^{\text {th }}$ Cir. 2012) (citing Dellar); Maxtone-Graham v. Burtchaell, 803

F.2d 1253, 1254 (2d Cir. 1986) (citing Dellar); Acuff-Rose Music v. Campbell, 972 F.2d 1429, 1439 (6th

Cir. 1992) (Nelson, J., dissenting) (citing Dellar), rev'd Campbell v. Acuff-Rose Music, 510 U.S. 569 (1994). 
numerous courts, commentators, legal practitioners and users. ${ }^{6}$

The Ninth Circuit Court of Appeals recently observed,

In the years following the 1976 Act, courts have decided countless cases involving the fair use doctrine. Some commentators have criticized the factors, labeling them "billowing white goo" ${ }^{77}$ or naught but a fairy tale," echoing courts that threw up their hands because the doctrine is so flexible as virtually to defy definition." Princeton Univ. Press v. Mich. Doc. Servs., Inc., 99 F.3d 1381, 1392 (6th Cir. 1996) (citation omitted). A leading treatise in this area notes that the statute provides "no guidance as to the relative weight to be ascribed to each of the listed factors," and, in the end, "courts are left with almost complete discretion in determining whether any given factor is present in any particular use." Nimmer on Copyright § 13.05[A].

Judge Pierre N. Leval explained in his seminal article on fair use,

The assumption of common ground is mistaken. Judges do not share a consensus on the meaning of fair use. Earlier decisions provide little basis for predicting later ones. Reversals and divided courts are commonplace. The opinions reflect widely differing notions of the meaning of fair use. Decisions are not governed by consistent principles, but seem rather to result from intuitive reactions to individual fact patterns. Justification is sought in notions of fairness, often more responsive to the concerns of private property than to the objectives of copyright. $^{8}$

Treatise writers have expressed similar views:

\footnotetext{
${ }^{6}$ The uncertainty of fair use in the US is particularly problematic when one considers the high cost of litigation. "One recent survey found that as of 2011, the median cost for litigating a copyright infringement lawsuit with less than $\$ 1$ million at risk was $\$ 350,000$." This expense puts small copyright owners at a disadvantage. Copyright Office, Notice of Inquiry on Remedies for Small Copyright Claims, 76 Fed. Reg. 66758, 66759-60 (Oct. 27, 2011), citing AM. INTELLECTUAL PROP. LAW ASS'N REPORT OF THE ECONOMIC SURVEY 2011 at 35 (2011).

${ }^{7}$ Monge v. Maya Magazines, 688 F.3d at 1171 (footnotes omitted).

${ }^{8}$ Pierre N. Leval, Towards a Fair Use Standard, 103 HARV. L. REV. 1105, 1106 (1990).
} 
No copyright doctrine is less determinate than fair use. Indeterminacy may be a necessary cost of a fact-specific doctrine that aims to negotiate liability in situations too fine-grained for Congress to address specifically in the statute. But it is nonetheless a source of frustration to the lawyer who needs to know whether his or her client can safely proceed with a project that skirts the edges of liability, and writers have sought for decades to bring order and predictability in the doctrine. ${ }^{9}$

As many fair use decisions correctly note, however, even the most recent precedent is of limited value because fair use is highly fact-specific and contextdependent. Predicting outcomes is more difficult than in other areas of copyright law. As the Second Circuit noted in American Geophysical Union v. Texaco, "[f]air use is a doctrine the application of which always depends on consideration of the precise facts at hand."10

Although that formulation [Take not from others to such an extent and in such a manner that you would be resentful if they so took from you] scarcely resolves concrete cases, it provides the beginning of wisdom by acknowledging that rigid application of set formulae may itself prove inexact. In the end, reliance on the four statutory factors to reach fair use decisions often seems naught but a fairy tale. $^{11}$

We are not suggesting that reasonable judgments cannot be made about whether a use is fair; not only have some academics posited an overall coherence to the case law, but experienced practitioners give fair use advice on a daily basis. But fair use decisions are often complicated, and advice frequently depends as much on the amount of risk the user is willing to undertake as it does on the evaluation of the substantive law. Legal opinions are usually accompanied by various explanations and disclaimers concerning the uncertainty of fair use.

\footnotetext{
${ }^{9} 2$ PAUL GoldSTEIN, GoldSTEIN ON COPYRIGHT $\$ 12.1$ (2013).

${ }^{10}$ Robert CLARIDA, COPYRIGHT LAW DESKBOOK, Ch. 6.I.A.1.b.i (2009 \& 2012 Supp.) (citation omitted).

${ }^{11}$ David Nimmer, "Fairest of them All" And Other Fairy Tales of Fair Use, 66 LAW \& CONTEMP. PROBS. 263, 287 (2003). See Richard Dannay, Factorless Fair Use? Was Melville Nimmer Right?, 60 J. COPYRIGHT SOC'Y $127,132-35$ (2013).
} 
Our point is not that fair use caselaw absolutely resists synthesis (after all, the current section 107 is itself a synthesis of the prior hundred years of caselaw), but rather that the synthesis most successfully occurs at a high level of abstraction; individual actors, by contrast, need to know whether their particular plans will run afoul of the law. It is important, we believe, to distinguish the academic's exercise of analyzing every fair use decision from the counselor's assessment of what kinds and quantities of copying not only will support a successful fair use defense, but - far more importantly to the user - will avoid attracting a lawsuit in the first place.

Providing ex ante advice or rules remains difficult even for many sophisticated attorneys. For example,

From the ex post perspective of the defendant already embroiled in expensive litigation, an adaptable, equitable defense is useful. But for the prospective defendant wondering whether a given act will prove infringing, fair use is too ambiguous to provide much ex ante guidance. ${ }^{12}$

Fair use in copyright law is one of the more challenging and unpredictable legal tests around. Even those of us who frequently deal with it find it difficult to provide hard-and-fast guidance. As I wrote a few years ago, it's simply not possible to honestly give simple, clear, advance fair use guidelines for the multitude of situations that come up. ${ }^{13}$

As Mary Rasenberger, a copyright attorney who has worked for the Library of Congress and the US Copyright Office, as well as in private practice, explained in a recent symposium concerning updating the library copying privileges of section 108 :

[F]air use is, as has been said many times [at] today['s symposium], really hard to use, and it requires lawyers. And even those of us who spend most of our

\footnotetext{
${ }^{12}$ James Gibson, Risk Aversion and Rights Accretion in Intellectual Property Law, 116 YALE L. J. 882, 889 (2007) (citation omitted).

${ }^{13}$ Mark Sableman, Fair Use Explained - or Not?, INTERNET LAW TWISTS \& TURNS (July 11, 2013) http://www.thompsoncoburn.com/news-and-information/internet-law-twists-and-turns/blog/13-0711/fair-use-explained-\%e2\%80\%93-or-not (last visited July 30, 2013).
} 
careers in copyright and spend a lot of time making fair use analysis, we don't always agree; there are a lot of close calls. It's hard. Fair use is really hard. ${ }^{14}$

Many users who have to make decisions on a daily basis seek greater certainty than fair use can provide. For example, archivist William Maher has commented:

We would like to see the clarity of exceptions as [the specific provisions of] section 108 can provide as opposed to the vagueness of "fair use" in section 107. And we do not want to have to depend on having things worked out in court, as is the case with section $107 .^{15}$

Eric Schwartz, an attorney who has long been involved with archiving films and sound recordings, explained:

[M]y work with libraries and archives tells me that what most working archivists want is certainty. If I start to respond to a question from an archivist by saying, "Fair use is fact determinative, it is very complicated, let me begin with the four factors, et cetera," the archivists I work with say, "Stop, I cannot do it," because the law of fair use does not make any sense to them, and it does not actually help them in a practical sense. ${ }^{16}$

Guidelines can alleviate some of this tension; we discuss guidelines in the following section.

Why is fair use so complicated? There are many reasons, but fundamentally, any rule that privileges flexibility necessarily produces unpredictability. The greater the former, the greater also the latter. But we suggest there may be an additional reason, of particular relevance to the ALRC's inquiry. Fair use is an on/off switch, all or nothing. Either the challenged use is an infringement of copyright, or it is a fair use, which section 107 declares "is not an infringement of copyright." As a result, either the copyright owner can stop the use, or the user not only is dispensed from obtaining permission, but also owes no compensation for the use. In US copyright law, "fair use" means "free" use, in both senses of the word.

\footnotetext{
${ }^{14} 36$ COLUM. J. L. ARTS 527, 593-94 (2013, forthcoming); Symposium, Session 4: Conditions on Libraries Digitizing Copyrighted Works.

${ }^{15} 36$ COLUM. J. L. ARTS 527, 596 (2013, forthcoming); Symposium, Session 4: Conditions on Libraries Digitizing Copyrighted Works.

${ }^{16} 36$ ColUM. J. L. ARTS 527, 553 (2013, forthcoming); Symposium, Session 2: Section 108 Issues Other Than Mass Digitization.
} 
The unpaid nature of fair use introduces pressures that may distort analysis, particularly of the "transformative" character of the use, and of potential market harm. Faced with a use, particularly in the context of new technologies, that a court perceives to be socially beneficial, a court may overemphasize its "transformativeness" and correspondingly underestimate the market consequences, in order to prevent the copyright owner from frustrating the social benefit. Distortions can appear in the other direction as well: a court sensitive to the economic consequences of the unpaid use may feel obliged to downplay the public interest fostered by the use. Statutory licenses can alleviate these pressures by ensuring that uses which the legislator perceives to be in the public interest proceed free of the copyright owner's veto, but with compensation. The paucity of such statutory licenses in the US may account to some extent for the long-standing disarray of fair use caselaw.

The ALRC Discussion Paper, which suggests that the Beebe ${ }^{17}$ and Samuelson ${ }^{18}$ articles indicate that fair use in the United States is on the verge of becoming coherent and predictable, seems to place inordinate weight on those articles. Numerous articles on fair use in the United States are published each year. ${ }^{19}$ Legal literature has seen many attempts over the years to simplify or clarify fair use, both descriptive and prescriptive. ${ }^{20}$ The exception remains difficult to apply. ${ }^{21}$

${ }^{17}$ See ALRC Discussion Paper 84, citing Barton Beebe, An Empirical Study of US Copyright Fair Use Decisions, 1978-2005, 156 U.PA. L. REV. 549 (2008).

${ }^{18}$ Pamela Samuelson, Unbundling Fair Uses, 77 FordhAM L. ReV. 2537 (2009). The ALRC also cites Matthew Sag, Predicting Fair Use, 73 OHIO St. L. J. 47 (2012).

19 See Richard Dannay, Factorless Fair Use? Was Melville Nimmer Right?, 60 J. COPYRIGHT Soc'Y 127, 14142 (2013) (collecting various articles with proposals to "fix" fair use). Barton Beebe has estimated that there are far more law review articles than there are published opinions on fair use. Beebe, supra note 17 at 565 n. 64. See also Symposium: Fair Use: "Incredibly Shrinking" or Extraordinarily Expanding?, 31 COLUM. J. L. ARTS 433-65 (2008).

${ }^{20}$ E.g., Michael J. Madison, A Pattern-Oriented Approach to Fair Use, 45 WM. \& MARY L. ReV. 1525 (2004); Justin Hughes, Fair Use Across Time, 50 UCLA L. Rev. 775 (2003); Pierre N. Leval, Toward a Fair Use Standard, 103 HARV. L. ReV. 1105 (1990); William W. Fisher III, Reconstructing the Fair Use Doctrine, 101 HARV. L. ReV. 1661 (1988). See also Matthew W. Wallace, Analyzing Fair Use Claims: A Quantitative and Paradigmatic Approach, 9 U. MIAMI ENT. \& SPORTS L. REV. 121 (1992). It is not our intention to provide a comprehensive survey of the fair use literature; we have merely provided some examples.

${ }^{21}$ We do not mean to detract in any way from the fair use scholarship cited in the ALRC Discussion Paper, but merely to recognize that it would be a mistake to conclude that the US is on the verge of clarifying or simplifying the application of the fair use doctrine in any significant way. 
We suggest that it is premature to conclude that commentators have clarified fair use and that, going forward, the law will be consistent and predictable.

\subsection{Fair Use Guidelines}

It is precisely because fair use is neither clear nor predictable that people seek the greater certainty that guidelines can provide. In our earlier report, we described various guidelines developed before or shortly after the passage of the 1976 Copyright Act to assist users and right holders in applying the fair use doctrine in the educational context, and, in particular, the guidelines that were included in congressional reports. ${ }^{22}$

Our aim was not to provide a substantive evaluation of those guidelines, but to describe what they were and how they came about. We agree with those who criticize certain courts for turning them into a ceiling rather than a floor. ${ }^{23}$ The guidelines themselves indicate that was not the intention. ${ }^{24}$

Although Congress arguably gave its imprimatur to these guidelines by including them in the legislative history, ${ }^{25}$ it is not our understanding that any of those guidelines were agreed to by all relevant interested parties. However, it appears that these guidelines did involve negotiations between participants with competing interests. We find frankly perplexing the argument made in one of the comments on the ALRC Discussion Paper, repudiating the Classroom Photocopy Guidelines on the ground that user groups had insufficient role in their development, yet embracing the more recent, unilaterally-developed "Best Practices" as superior because right holders had no role in their development. ${ }^{26}$

We believe that guidelines can be useful, provided they are developed with input from right holders and users, are reasonably clear and not unduly rigid. The degree to which guidelines can be followed with confidence, and the legal weight they are accorded, depends in

${ }^{22}$ Kernochan Center Report, supra note 2 at 25-31.

${ }^{23}$ See Kenneth D. Crews, The Law of Fair Use and the Illusion of Fair Use Guidelines, 62 OHIO ST. L. J. 599, 640-41 (2001).

${ }^{24}$ Agreement on Guidelines for Classroom Copying in Not-for-Profit Educational Institutions with Respect to Books and Periodicals, H.R. REP. No. 94-1476 at 68-70 (1976).

${ }^{25}$ But see Crews, supra note 23 at $672-73$.

${ }^{26}$ See Gwen Hinze, Peter Jaszi \& Matthew Sag, The Fair Use Doctrine in the United States - A Response to the Kernochan Center Report (July 26, 2013), Submission 483, available at http://www.alrc.gov.au/inquiries/copyright-and-digital-economy/submissions-received-alrc\#DPind. 
large part on how they are developed. Guidelines embodied in administrative regulations after a notice and comment period in which all sides had an opportunity to comment are entitled to the deference shown to other administrative rules. To the extent guidelines represent custom developed over a long history of dealings between owners and users, a court may take them into consideration as evidence of what is customary and reasonable in an industry. ${ }^{27}$ But guidelines that represent the aspirations of one set of players ${ }^{28}$ would likely be of doubtful legal significance in a court as evidence of substantive law. Developing guidelines to assist in the application of fair use with input from all of the relevant parties is a worthwhile goal, even though the US experience, for example with CONFU, ${ }^{29}$ indicates that it is a formidable task.

However, recent developments indicate that it is possible to arrive at multilateral agreements concerning the use of copyrighted works. For example, the Section 108 Study Group (divided roughly 50-50 between copyright owners on the one hand, and users, including librarians and archivists, on the other) arrived at several recommendations concerning legislative changes to update library exceptions for the digital environment. While some of the recommendations were made at a very high level, others were fairly detailed. ${ }^{30}$ What is particularly notable about

27 See generally Jennifer Rothman, The Questionable Use of Custom in Intellectual Property, 93 VA. L. REV. 1899 (2007); Richard A. Epstein, Some Reflections on Custom in the IP Universe, 93 VA. L. REV. 223 IN BRIEF (2008).

${ }^{28}$ The comment by Hinze et al., supra note 26 at 10, characterizes the Best Practices as a sincere attempt to describe circumstances in which the unauthorized use of copyrighted material is "crucial to the fulfillment of that community's shared artistic or informational mission." We appreciate the Best Practices' endeavor to articulate user communities' perceived needs, but a user group's shared perception that uncompensated copying and communication of works of authorship is critical to its mission does not suffice to make the desired use "fair," particularly if the interests of the user group align almost exclusively in favor of limiting the scope of copyright. In that respect, user-generated guidelines expressing the needs of a community, such as documentary filmmakers, whose members are both copyright owners and users should enjoy greater credibility than the assertions of the needs of less balanced constituencies. See ASS'N OF INDEPENDENT VIDEO AND FILMMAKERS ET. AL., DOCUMENTARY FILMMAKERS' STATEMENT OF BEST PRACTICES IN FAIR USE (Nov. 18, 2005), available at http://www.cmsimpact.org/fairuse/best-practices/documentary/documentary-filmmakers-statement-best-practices-fair-use

${ }^{29}$ See Kernochan Center Report, supra note 2 at 31-32 (discussion of CONFU); see generally Crews, supra note 23 at 626-35.

${ }^{30}$ See SECTION 108 STUDY GROUP REPORT iii-xiv (Mar. 2008), available at http://www.section108.gov 
the Section 108 Study Group is that its recommendations were made based on unanimous consensus of the group. ${ }^{31}$

\subsection{If the ALRC's Recommendations Were Enacted, the Fair Use Exception in Australia Could Be Broader Than in the US}

Certain aspects of the ALRC's Discussion Paper and recommendations suggest that, if those recommendations were adopted, fair use in Australia could be broader than it is in the United States. For example, the additional illustrative purposes would likely contribute to the breadth of fair use in Australia, especially such potentially elastic purposes as "private and domestic use." Other aspects of the ALRC's proposal that could contribute to a broader fair use regime in Australia include: (i) the suggestion that commercial entities be permitted to "stand in the shoes" of the user; (ii) the proposal that certain fair use and library exceptions "trump" contracts; and (iii) the suggestion that certain fair use and library exceptions be an acceptable basis for circumventing technological protections on copyrighted works. The first two topics are addressed in this section; technological protection is addressed separately in section 5.0.

\section{1 "Standing in the Shoes"}

While the ALRC Discussion Paper does not recommend that third parties automatically be entitled to rely on the fair use exceptions of their customers, it does suggest various scenarios in which such reliance should be permissible. ${ }^{32}$

US law is not entirely consistent, but in numerous instances US courts have declined to permit third party for-profit businesses to claim the same privileges and defenses as their customers. Such commercial entities have not been permitted to assert a fair use defense simply because

${ }^{31} I d$. at ii. Other examples of cooperation between copyright holders and users include the UGC Guidelines (agreements between right holders and UGC sites concerning the take-down of allegedly infringing material), see Alan M. Braverman and Terri Southwick, The User-Generated Content Principles: The Motivation, Process, Results and Lessons Learned, 32 ColUM. J. L. \& ARTS 471 (2009), and the Copyright Alert System in which certain ISPs have agreed to remove CAS-registered copyrighted content reproduced without authorization through Bit Torrent and peer-to-peer file sharing. Known as the "six strikes rule," the system provides for a graduated series of warnings to ISP customers who repeatedly engage in posting copyrighted content of others. The Copyright Alert System, CENTER FOR COPYRIGHT INFORMATION, http://www.copyrightinformation.org/the -copyright-alert-system/ (last visited July 30, 2013).

32 See generally, ALRC Discussion Paper at 99-108. 
they are committing an act that customers might be able to claim as fair use if they were doing the act themselves.

For example, in Basic Books, Inc. v. Kinko's Graphics Corp., the United States District Court for the Southern District of New York concluded that while students may be permitted to copy materials needed for class, commercial copying services that copy the same materials for financial gain are not. ${ }^{33}$ The court wrote

The use of the Kinko's packets, in the hands of the students, was no doubt educational. However, the use in the hands of Kinko's employees is commercial. Kinko's claims that its copying was educational and, therefore, qualifies as fair use. Kinko's fails to persuade us of this distinction. ${ }^{34}$

The United States Court of Appeals for the Sixth Circuit came to a similar conclusion in Princeton University Press v. Michigan Document Services, ${ }^{35}$ a case in which academic publishers sued a copy shop that was producing course packs for students at a local university. Professors would provide master copies of the class materials to the copy shop, which would reproduce the materials and sell them to students registered for the professors' classes. While the Sixth Circuit acknowledged that the students might have been protected under the fair use doctrine had they individually copied the material for use in class, it found this of little consequence:

We need not decide this question, however, for the fact is that the copying complained of here was performed on a profit-making basis by a commercial enterprise. And "[t]he courts have. . . properly rejected attempts by for-profit users to stand in the shoes of their customers making nonprofit or noncommercial uses." 36

This case has been cited in a number of fair use cases where one party is attempting to claim a defense available to another. ${ }^{37}$

${ }^{33}$ Basic Books, Inc. v. Kinko's Graphics Corp., 758 F. Supp. 1522 (S.D.N.Y. 1991).

${ }^{34}$ Id. at 1531.

35 Princeton Univ. Press v. Michigan Document Servs., 99 F.3d 1381 (6th Cir. 1996).

${ }^{36}$ Id. at 1389 (citing William F. PATRY, THE FAIR USE PRIVILEGE IN COPYRIGHT LAW 420 n. 34 (1995)).

${ }^{37}$ E.g., Blackwell Publ'g, Inc. v. Excel Research Gr., LLC, 661 F. Supp. 2d 786, 791, 793 (E. D. Mich. 2009) (holding that while student copying was allowed under the license from the copyright owners of the material, Excel was not a licensee and, as it garnered commercial gain from the students' use of the 
The principle that commercial entities may not stand in the shoes of customers who may be entitled to an exception is not limited to course packs. For example, in Pacific \& Southern Co. v. Duncan, the United States Court of Appeals for the Eleventh Circuit refused to recognize a fair use defense advanced by a video news clipping service on the basis that it was engaging in "private news reporting" for its customers' personal use. ${ }^{38}$ The court observed that TV News Clips' copying was "unabashedly commercial" despite the use to which the customers put their copy. The court explained:

Of course, every commercial exchange of goods and services involves both the giving of the good or service and the taking of the purchase price. The fact that TV News Clips focuses on the giving rather than the taking cannot hide the fact that profit is its primary motive for making the exchange. ${ }^{39}$

In another context, Infinity Broadcasting Corporation ${ }^{40}$ sued Wayne Kirkwood for retransmitting broadcasts of Infinity-owned radio stations over telephone lines. Kirkwood argued that its activities were protected by fair use, but the court concluded that Kirkwood's wholesale retransmission of various radio stations' 24-hour broadcasts was not a fair use. ${ }^{41}$ It rejected Kirkwood's claim that his service was analogous to a photocopier in a library, citing Princeton University Press and Basic Books, discussed above, for the proposition that large-scale photocopying even for customers with a statutorily approved purpose can be infringing. ${ }^{42}$

store's equipment and staff, it was liable for copyright infringement). See also Atl. Recording Corp. v. XM Satellite Radio, Inc., No. 06 Civ. 3733 (DAB), 2007 WL 136186 at *7 (S.D.N.Y Jan. 19, 2007) (while some satellite radio subscribers may store audio files downloaded from broadcast performances on their MP3 players for private use, this does not mean that a satellite radio provider may offer such a commercial service).

38 Pac. \& S. Co. v. Duncan, 744 F.2d 1490, 1496 (11th Cir. 1984).

${ }^{39}$ Id. See also Authors Guild v. HathiTrust, 902 F. Supp. 2d 445, 448 \& 462 n. 27 (S.D.N.Y. 2012) (finding libraries' use of copies made by Google to be fair use, but not addressing the liability of Google, which created the copies on the libraries' behalf (and on its own), since that is the subject of another suit).

${ }^{40}$ Infinity Broad. Corp. v. Kirkwood, 150 F. 3d 104, 106 (2d Cir. 1998).

${ }^{41} / d$. at $111-12$.

${ }^{42}$ Id. at 112. 
In Clean Flicks of Colorado, LLC v. Soderbergh, a Utah company edited mainstream films in order to remove what it felt were offensive portions, and sold copies of the edited versions to customers who preferred wholesome, family-friendly versions of the films. Clean Flicks was found liable for copyright infringement. ${ }^{43}$ Although the Family Movie Act of $2005^{44}$ allows for at-home use (and the commercial sale) of video-editing technology, Clean Flicks' activities were not a fair use. ${ }^{45}$

\subsection{Invalidating Contracts}

The ALRC has proposed to amend the Australian Copyright Act to render unenforceable contracts or contractual terms excluding or limiting the operation of libraries and archives exceptions, and the proposed fair use exception (in relation to fair uses for the purpose of research or study; criticism or review; parody or satire; reporting news; and quotation). ${ }^{46}$ The report compares this provision with US law, stating that "US law has developed copyright specific constraints on the freedom of parties to contract out of copyright exceptions, based on the doctrines of copyright preemption and copyright misuse." ${ }^{47}$ However, under US law neither contract preemption nor copyright misuse are generally perceived (or used) as tools to invalidate contract provisions solely because they prohibit the exercise of copyright exceptions. Copyright misuse can result in invalidating a contract or contract provisions, but only in egregious cases where the contract does not merely preclude the licensee from taking advantage of a copyright exception, but does so in a manner that contravenes the fundamental public policies underlying the copyright law.

${ }^{43}$ Clean Flicks of Colorado, LLC v. Soderbergh, 433 F. Supp. 2d 1236 (D. Colo. 2006).

${ }^{44}$ Pub. L. No. 109-9, 119 Stat. 218, 223-224 (2005), codified in 17 U.S.C. § 110 (11).

${ }^{45}$ Clean Flicks, 433 F. Supp. $2 d$ at 1240-43. The statutory exception for the in-home use and sale of the video-editing technology, enacted during the pendency of the Clean Flicks suit, depends on not making a retention copy of the edited version, and thus Clean Flicks' activities were not covered. The court concluded that Clean Flicks' activities were not fair use, even though Clean Flicks had contended that there was no market harm because Clean Flicks required its customers also to buy an unedited version of the motion picture that Clean Flicks had edited.

${ }^{46}$ ALRC Discussion Paper at 353.

47 ALRC Discussion Paper at 361. The Discussion Paper significantly qualifies this statement in subsequent discussion. Id. at 361-62. 


\subsubsection{Preemption}

US copyright law preempts all legal or equitable rights under state law that are equivalent to any of the exclusive rights within the general scope of copyright as specified by section 106 in works of authorship that are fixed in a tangible medium of expression and come within the subject matter of copyright. ${ }^{48}$ A state law-based right is not deemed the "equivalent" of copyright rights if the state law cause of action "contains an operative element that is absent from the cause of action for copyright infringement." ${ }^{49}$ Contract law "is a good example of a state law that will be immune from preemption under the extra element test"; the bargainedfor exchange or the promise to pay can be viewed as the extra element that precludes preemption. ${ }^{50}$ As the ALRC Discussion Paper observes, US law places few restrictions on parties to contract around copyright exceptions as they wish. In fact, in the US, parties are generally free to contract out of copyright exceptions or limitations, and do so every day. Such contracts do not trigger copyright preemption. ${ }^{51}$

For example, distinguished individuals - or their estates - may be reluctant to deposit private letters and papers in a library or archives without contractual assurances as to how those materials will be used. Indeed, one of the chief reasons for the provision in section 108 of US law, which specifically preserves the parties' right to contract, was to ensure that libraries could enter into enforceable agreements with donors of manuscripts and private papers who want assurances that their materials will not be reproduced. ${ }^{52}$

A publisher may provide libraries, schools and/or academic users with access to a database at a rate significantly below that charged to commercial users but with restrictions on how that database may be used. For example, a limitation on use of the database to "noncommercial purposes" might preclude a student from using the database for his part-time job for a forprofit entity, even if that use constituted fair use. But such a contractual undertaking isn't invalid or unfair.

\footnotetext{
4817 U.S.C. $\S 301(a)$.

${ }^{49} 3$ GoldSTEIN ON COPYRIGHT §17.2.1.2 (citations omitted).

${ }^{50} I d$.

51 As the ALRC Discussion Paper recognizes, one notable exception is termination rights. See, e.g., 17 U.S.C. $\S 203(\mathrm{a})(5)$.

${ }^{52}$ H.R. Rep. No. 94-1476 at 77 (1976).
} 
Similarly, a publisher may limit who has access to a copyrighted work, by the number of simultaneous users, by restrictions on the nature of users (e.g., to faculty, staff, students and walk-ins) on the permissible venues for use, etc. These restrictions may reflect the manner in which the publisher has priced its product, concerns about the ease of infringement, differing copyright laws in other jurisdictions, and so on. Such provisions are generally valid.

\subsubsection{Copyright Misuse}

The "copyright misuse defense" does not invalidate contract provisions simply because they prohibit the exercise of copyright privileges with respect to the licensed material. The copyright misuse doctrine has been limited to only the most egregious of conduct with respect to copyrighted works.

The copyright misuse doctrine was founded on the doctrine of patent misuse, established by the Supreme Court in Morton Salt Co. v. G.S. Suppiger Co. in $1942 .{ }^{53}$ In Lasercomb America v. Reynolds, ${ }^{54}$ the United States Court of Appeals for the Fourth Circuit held for the first time that copyright misuse is a valid defense to a copyright infringement action, regardless of whether the party asserting misuse can prove an antitrust violation. ${ }^{55}$ The contract at issue in that case, a license for software developed by Lasercomb, prohibited licensees from creating any computer program that performed the same functions as Lasercomb's (even if they made no use of Lasercomb's) for ninety-nine years, which the court observed could be longer than the term of the copyright. ${ }^{56}$ The court concluded that Lasercomb's contract contravened the public policies underlying the copyright system by prohibiting its licensees' employees from using their "creative abilities." 57

Whether a court will sustain a copyright misuse defense depends upon whether a copyright owner is using its copyright in a manner contrary to the public policies underlying copyright

\footnotetext{
${ }^{53}$ Morton Salt Co. v. G.S. Suppiger Co., 314 U.S. 488 (1942), abrogated by Illinois Tool Works Inc v. Indep. Ink, Inc., 547 U.S. 28 (2006).

${ }^{54}$ Lasercomb America v. Reynolds, 911 F.2d 970 (4th Cir. 1990).

${ }^{55}$ Id. at $977-78$.

${ }^{56}$ Id. at 978 .

${ }^{57} / d$.
} 
law. ${ }^{58}$ Once an affirmative defense of copyright misuse has been proven, the copyright owner is prevented from enforcing its copyright and bringing suits for infringement until it demonstrates that it has purged itself of misuse. ${ }^{59}$

After Lasercomb, a violation of antitrust law may be sufficient but is not necessary for copyright misuse. Since that case was decided, the majority (but not all) of U.S. circuit courts have recognized the copyright misuse defense. The only standard that courts apply to such agreements is that they are "egregious" or obviously overreaching. ${ }^{60}$ Since Lasercomb many alleged infringers have asserted this defense, and most have failed. ${ }^{61}$ The courts uphold this defense very sparingly; only a handful of cases have found copyright misuse. Two of these are circuit court cases dealing with licensing agreement provisions that involved "tying" the copyright license to unprotected subject matter, or which were otherwise egregiously anticompetitive. ${ }^{62}$ The third was a straightforward district court case where the copyright owner attempted to assert a copyright over material in which it held no rights. ${ }^{63}$

\subsection{Technological Protection}

Section 1201 of Title 17, enacted as part of the DMCA, prohibits the act of circumventing a technological protection measure (TPM) that "effectively controls access" to a work protected by copyright. $^{64}$

${ }^{58}$ Id. at $978-79$

${ }^{59}$ Id. at 979, n. 22.

${ }^{60}$ See In re Napster Copyright Litigation, 191 F. Supp. 2d 1087, 1104-05 (N. D. Cal. 2002).

${ }^{61}$ E.g., Apple Inc. v. Psystar Corp., 658 F. 3d 1150, 1159 (9th Cir. 2011) (Apple's license requirement that MAC OS X be run only on Apple computers not copyright misuse); Video Pipeline, Inc. v. Buena Vista Home Entm't, Inc., 342 F. 3d 191, 206 (3d Cir. 2003) (licenses that restrict licensed Disney trailers to nonderogatory use do not significantly interfere with the policies underlying copyright).

${ }^{62}$ Practice Mgmt. Info. Corp. v Am. Med. Ass'n, 121 F. 3d 516, 518 (9th Cir. 1997) (Practice Management sought to bar a federal agency from using any competing coding system.); Alcatel USA, Inc. v. DGI Techs., Inc., 166 F.3d 772, 793 (5th Cir. 1999) (Alcatel sought through its copyright license to prohibit anyone from developing a competing microprocessor card, even though it had not patented the card).

${ }^{63}$ qad, Inc. v. ALN Assocs., Inc., 770 F. Supp. 1261 (N.D. III. 1991), aff'd on other grounds, 974 F.2d 834 (7th Cir. 1992).

6417 U.S.C. $\$ 1201(a)(1)$. The DMCA also contains two provisions that prohibit trafficking in devices or services to circumvent TPMs. The first prohibits manufacturing, importing, offering to the public, providing or otherwise trafficking in technologies, products or services that are: (1) primarily designed or 
Section 1201 provides a number of exemptions that excuse conduct that would otherwise violate the prohibition on circumventing access controls. ${ }^{65}$ The Librarian of Congress has the authority to create additional exemptions based on the record established in a triennial rulemaking proceeding conducted by the U.S. Copyright Office. ${ }^{66}$ Those additional exemptions last only three years; each rulemaking proceeding considers the exemptions de novo.

There is no blanket exemption in section 1201 that allows a user to circumvent access controls to make a fair use of the underlying work. Courts on several occasions have declined to read one into the statute. ${ }^{67}$ For example, in Universal City Studios v. Corley, ${ }^{68}$ the United States Court of Appeals for the Second Circuit rejected defendant's argument that fair use of DVD movies is "constitutionally required," holding that the DMCA does not impose any limitation on the opportunity to make a variety of traditional fair uses of DVD movies. According to the court,

produced to circumvent a technological measure that effectively controls access to a copyrighted work, or (2) that have only limited commercially significant purpose or use other than to circumvent such controls, or (3) that are marketed for use in circumventing such controls. Second, the DMCA prohibits trafficking in devices or services to circumvent technological rights controls (mechanisms that restrict copying the work or playing it in a particular environment without authorization). There is no prohibition on the act of circumventing rights controls.

${ }^{65}$ These exemptions include those for: nonprofit libraries, archives and educational institutions to allow them to determine whether or not they would like to acquire a work, §1201(d); law enforcement, intelligence, and other government activities, §1201(e); reverse engineering of computer programs for the sole purpose of identifying and analyzing elements of the program necessary to achieve interoperability with other programs, §1201(f); encryption research, §1201(g); protection of minors by preventing their access to materials on the internet, $\$ 1201(\mathrm{~h})$; circumvention with the sole effect of identifying and disabling the capability of a TPM to collect personally identifying information, §1201(i); and security testing, $§ 1201(\mathrm{j})$.

${ }^{66}$ See 17 USC § 1201(a)(1)(B)-(E).

${ }^{67}$ E.g., Universal City Studios v. Corley, 273 F.3d 429 (2d Cir. 2001); see 321 Studios v. MGM Studios, Inc., 307 F. Supp. 2d 1085 (N. D. Cal. 2004); Eyepartner, Inc. v. Kor Media Grp. LLC, 2013 U.S. Dist. Lexis 98370 (S.D. Fla. July 15, 2013).

${ }^{68}$ Corley, 273 F.3d at 429. 
"Fair use has never been held to be a guarantee of access to copyrighted material in order to copy it by the fair user's preferred technique or in the format of the original." 69

In the triennial rulemakings, the Register of Copyrights and the Librarian of Congress have consistently refused to grant exemptions for broad categories like "fair use works" or "educational fair use works," for "all noninfringing uses" or for "any work to which a user had initial lawful access." 70 Initially the Register interpreted the statute as requiring that an exemption be based on a class of works, and therefore described solely with reference to the works subject to the exemption rather than on the users or the types of uses. ${ }^{71}$ This approach eventually became unworkable: the Office was in the position of denying certain narrow exemptions it deemed warranted, rather than creating an exemption solely with reference to the class of works, which would be far broader than necessary to accommodate those specific uses. $^{72}$

Accordingly, in 2006 the Register concluded that while the class of works eligible for circumvention must be identified initially by type of work, that class may be refined and limited based on the particular use. ${ }^{73}$

${ }^{69}$ Corley, 273 F.3d at 459.

${ }^{70}$ See, e.g., Exemption to Prohibition on Circumvention of Copyright Protection Systems for Access Control Technologies; Final Rule, 65 Fed. Reg. 209, 64556, 64571 (Oct. 27, 2000), available at http://www.copyright.gov/fedreg/2000/65fr64555.pdf ("2000 Rule"); Register of Copyrights, Recommendation of the Register of Copyrights in RM 2002-4; Rulemaking on Exemptions from Prohibition on Circumvention of Copyright Protection Systems for Access Control Technologies 82-93 (Oct. 27, 2003), available at http://www.copyright.gov/1201/docs/registers-recommendation.pdf (“2003 Register's Report”).

${ }^{71}$ E.g., 2000 Rule at 645620; 2003 Register's Report at 83. See June Besek, Anti-Circumvention Laws and Copyright: A Report from the Kernochan Center for Law, Media and the Arts, 27 COLUM. J. L. \& ARTS 389, 399-405, 416-425 (2004).

${ }^{72}$ Register of Copyrights, Recommendation of the Register of Copyrights in RM 2005-11; Rulemaking on Exemptions from Prohibition on Circumvention of Copyright Protection Systems for Access Control Technologies 18-19 (Nov. 17, 2006) available at http://www.copyright.gov/1201/docs/1201 recommendation.pdf ("2006 Register's Report").

${ }^{73} / d$. at 17 . So, for example, in 2006 the Register recommended an exemption for "audiovisual works included in the educational library of a college or university's film or media studies department, when circumvention is accomplished for the purpose of making compilations of portions of those works for educational use in the classroom by media studies or film professors." Id. at 12. 
The unwillingness to create exemptions for such broad categories reflects recognition that TPMs are both access-limiting and access-enabling. Congress knew that in some cases TPMs might make the exercise of copyright exemptions more difficult, but it nevertheless decided that effective technological protections would encourage innovation in new content delivery mechanisms and provide consumers with a range of new options for experiencing copyrighted works. ${ }^{74}$ Broad exemptions could ultimately diminish rather than increase consumer access to protected works. The Copyright Office has concluded that narrow exemptions can be sought in future rulemaking proceedings for those "exceptional cases" where access for permitted uses is truly impeded.

\subsection{Conclusion}

We appreciate this opportunity to submit comments to the ALRC. We have endeavored in this submission to show that the US experience indicates that while fair provides flexibility, it also brings with it considerable uncertainty. It would be premature to conclude that going forward, fair use law in the US will be coherent and predictable.

As we have discussed above, aspects of the ALRC's discussion and recommendations suggest that if adopted, fair use in Australia could be broader than in the United States.

We reiterate our earlier caution that any analysis of the similarities and differences between US law and a proposed fair use exception in Australia is necessarily tentative, because US fair use law continues to develop and certain cases addressing fair use in the educational context are still in their early stages.

\section{New York, New York}

July 30, 2013

${ }^{74}$ See, e.g., 2000 Rule at 65 Fed. Reg. 64,563; 2003 Register's Report at 91-92; cf. MDY Indus., LLC v. Blizzard Entm't, Inc., 629 F.3d 928, 947-50 (9th Cir. 2010) (Congress intended to grant copyright owners an independent right to enforce the prohibition against circumvention of effective technological access controls regardless of whether there was a specific nexus to copyright infringement, to encourage copyright owners to make their works available in digital formats such as on-demand or pay-per-view which allow customers effectively to "borrow" a copy of work for a limited time or a limited number of uses.), amended and superseded on denial of rehearing, 2011 WL 538748 (9th Cir. Feb. 17, 2011). 


\section{Short Biographies of Authors}

Jane C. Ginsburg, Morton L. Janklow Professor of Literary and Artistic Property Law and Faculty Director, Kernochan Center for Law, Media and the Arts

B.A., Chicago, 1976; M.A. (History of Culture), Chicago, 1977; J.D., Harvard, 1980; D.E.A., Université de Paris II, 1985 (Fulbright grantee); Doctor of Law, Université de Paris II, 1995. Editor and note editor, Harvard LAW ReVIEW. Law clerk to Judge John J. Gibbons, U.S. Court of Appeals for the Third Circuit, 1980-81. Prof. Ginsburg spent three years in private practice and obtained a French law degree before joining the Columbia Law School faculty. She teaches U.S. and international and comparative copyright law, trademark law, and legal methods. Her publications on domestic and international copyright law include INTERNATIONAL COPYRIGHT AND Neighbouring Rights: The Berne Convention And Beyond (Oxford University Press 2006) (with Professor Sam Ricketson); COPYRIGHT LAW: CONCEPTS AND INSIGHTS, (Foundation Press 2012) (with Prof. Robert A. Gorman); CASes And MAterials On Copyright (with R.A. Gorman and Prof. R. Anthony Reese, 8th ed., 2011, and annual supplements); COPYRIGHT AND PIRACY: AN INTERDISCIPLINARy Critique, (Cambridge University Press 2010) (Editor, with Prof. Lionel Bently and Dr. Jennifer Davis); and many law review articles. With Professor Rochelle Dreyfuss and Professor François Dessemontet she was also a Co-Reporter for the American Law Institute project on Intellectual Property: Principles Governing Jurisdiction, ChOICE Of LAW ANd Judgments In Transnational Disputes. Prof. Ginsburg has taught French and U.S. copyright law at several French universities, and held the Goodhart Visiting Chair of Legal Science at the University of Cambridge, 2004-05. She serves on the editorial boards of several intellectual property journals in the United States and abroad. In 2011 she was elected a Corresponding Fellow of the British Academy, and in 2013 a Member of the American Philosophical Society.

June M. Besek, Executive Director, Kernochan Center for Law, Media and the Arts and Lecturer in Law, Columbia Law School

B.A. Yale, 1976; J.D. New York University School of Law, 1981. Ms. Besek clerked for Judge Charles H. Tenney in the Southern District of New York. Before coming to Columbia, she was Director of Intellectual Property at Reuters America Inc., and a partner at a New York City law firm where she practiced intellectual property law.

Much of her research over the past several years has focused on copyright implications of digital libraries, and she has worked in conjunction with CLIR and the Library of Congress on a number of projects. She was a member of the Section 108 Study Group. She has also focused on legal issues related to pre-1972 sound recordings. Her publications include "The Development of Digital Libraries in the United States," in Global Copyright: Three Hundred YearS SinCe the StATUte of ANne, from 1709 to Cyberspace (Lionel Bently et al., eds., Edward Elgar 2010); 
"Enabling Digital Preservation by Expanding the Library Exceptions in the US Copyright Act: The Section 108 Study Group," in Working Within the Boundaries of INTELleCtUAl Property: INNOVATION Policy fOR the KNowledge SOCIETy (Rochelle C. Dreyfuss et al., eds., Oxford Univ. Press 2010); Copyright and Related Issues ReleVant to Digital Preservation and Dissemination of UnPublished Pre1972 SOUND RECORDINGS by LIBRARIES AND ARCHIVES (CLIR \& Library of Congress, 2009); “Maintaining the Integrity of Digital Archives," 31 Colum. J. LAW \& ARTS 267 (2008) (with Philippa Loengard); "Anti-Circumvention Laws and Copyright: A Report from the Kernochan Center for Law, Media and the Arts," 27 Colum. J. L. \& ARTS 385 (2004); and Copyright IsSUes ReleVANT to the CREATION OF A Digital ArChive: A Preliminary AsSessment (CLIR \& Library of Congress 2003).

At Columbia, Ms. Besek teaches a seminar on Current Issues in Copyright with Prof. Jane Ginsburg, and a seminar on Authors, Artists and Performers. Ms. Besek serves on Council for the American Bar Association's Section of Intellectual Property Law, and is a former chair of the Copyright Division. She serves on the editorial board of the JOURNAL OF THE COPYRIGHT SOCIETY OF THE U.S.A., on the board of advisors of the COLUMBIA JOURNAL OF LAW \& THE ARTS, and on the Board of Volunteer Lawyers for the Arts in New York.

Philippa Loengard, Assistant Director, Kernochan Center for Law, Media and the Arts, Columbia Law School

B.A. Cornell, 1993; M.A. (Communication) Stanford, 1995 (Karl A. and Medira Bickel Fellowship); J.D. Columbia, 2003 (Harlan Fiske Stone Scholar, Articles Editor, ColumBIA JourNAL OF LAW \& THE ARTS); LL.M. (Taxation) NYU, 2009. Pippa Loengard is the Assistant Director of the Kernochan Center for Law, Media and the Arts and a Lecturer in Law at Columbia Law School where her teaching and research focus on copyright (especially as it pertains to the visual arts) and entertainment law. She co-teaches a seminar in Law and the Visual Arts with Jo Backer Laird. Her current research focuses on the taxation of artistic materials created in digital formats and on issues surrounding art authentication, topics on which she has spoken at conferences nationwide.

Ms. Loengard is a member of the Art Law Committee of the Association of the Bar of the City of New York and a past member of the City Bar's Entertainment Law Committee and of the Executive Committee of the EASLS section of the New York State Bar Association. In 2012 she was named to the Academic Advisory Board of the Copyright Alliance. She co-authored "Picture This: A Call for Uniformity in the Sales Tax Treatment of Digital Photographs," 35 COLUM. J. LAW \& ARTS 549 (2012) with Amanda DiSanto and "Maintaining the Integrity of Digital Archives," 31 COLUM. J. LAW \& ARTS 267 (2008) with June Besek. She was in private practice at Kramer Levin Naftalis \& Frankel LLP before joining the Kernochan Center staff. 